\title{
SKETCHES OF BABEL
}

One almost-gone afternoon in November, as I stepped out into what sun remained in the day, a proof for the existence of God took hold of me. I was a freshman in college and had just finished a meeting with a teaching assistant. The department house's heavy wooden door thudded shut behind me. Light; truth. A sensation flooded me with the semblance of logic, without the words to describe it or instructions to complete it. I still couldn't even say if I believed in a God or not. Yet there it was: a promissory note, at least, for propositions and definitions and conclusions to come, with the vowel-y echo in my ear of the word proof.

Hurrying down the steps and across campus, past the buildings standing at attention all around, I had no idea how to write my discovery down. Over the days and weeks that followed, sitting at a desk in my dorm room or under a winsome tree, I would start to think through its steps in words and sequence but then get stuck. Stuck-that's what I was, in more ways than one. The idea of a proof had caught me, or caught up to me. There was no

I

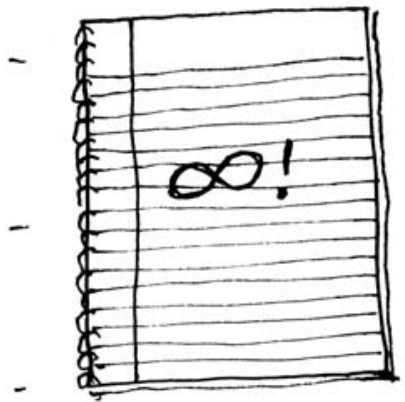
turning back. After just a few months, I would be baptized a believer.

I didn't tell anyone about this strange, problematic, unsatisfying thought then, nor would I know what to say if I had. But the germ of a proof was in me, somewhere, treasurelike-a blueprint for my own Tower of Babel. Dissatisfaction urged me on. Every once in a while I'd try again to spell it out and get a little bit further, and then get frustrated. Did it make sense, or not? Was it 
valid as logic, or even as a description of experience? I still can't say. Perhaps this book, a decade later, is one more attempt to be done with it.

The premise of Laurence Cossé's novel A Corner of the Veil is that someone discovers a proof of God's existence-a real proof, finally. A priest who has just seen it walks through the streets of Paris and looks at the people around him, imagining what it will be like when they, too, see what he has seen.

Probably, for a time, everything would come to a halt. People wouldn't go to the office anymore. The children would be sent to school, but they'd stop along the way, caught up by great circles of orators in tears.

People would talk on sidewalks, in the Métro, at church doors. Ah, the priests wouldn't know where to start! People would talk for hours in the rain. Neighbors who had always eyed each other with suspicion would be talking to each other. Couples ten years separated would phone each other from distant places.

The post office would stay closed. There would be a notice on the gate: HaLlelujah. On the other hand, the museums would never close again, nor the Métro, nor the public parks. The guards would never figure out where their caps had disappeared to.

For days it would feel like a kind of general strike, a huge drunken spree. ${ }^{I}$

Isn't this what we should rightfully expect of a proof? To claim, as a proof of God does, such certainty and finality about so exalted a thing should warrant nothing less than ecstasy. And some people do say there is proof. So why does this scene only come in a daydream, in a work of fiction?

Some will object to talking about proof at all. They'll say that any absolute or mathematical proof for God sets the bar too high, or too low. Instead, call it argument, or demonstration-or call it faith. But proof fits the story I'm trying to tell like no other word.

The Latin root is probare, which has to do with testing something to see if it's any good. It used to be more common to speak about proving as a kind of experience, something one has to go through or even suffer-as in, to prove oneself. Proving meant becoming, or growing. A thing proved might be a trip that turned out well, or well enough, or even just with you intact and unsullied. That's why we call a jacket waterproof when water can't get through. And that's part of what a proof for God promises to offer: a seal on every seam, an answer to every question, a rampart for every flank.

The remnants of these meanings have spread among the trades. Proofing dough is making it rise. Printers, engravers, and photographers all have their 
proofs, just as armies have their proving grounds. Lawyers look for proof in evidence. And distillers speak of proof as a mixture whose volume is 0.5727 pure alcohol—which would be an experience in itself.

So, yes, primarily what I mean by proof is the 1933 Oxford English Dictionary's definition I.I:

That which makes good or proves a statement; evidence sufficient (or contributing) to establish a fact or produce belief in the certainty of something.

And more. With every "that which makes good" comes a story, a test, a sojourn. Like a baker's proof, it forces one to grow a little, and, like a printer's, it won't always come out right the first time. Like the distiller's, it can be exhilarating. We can only hope that our proofs, like a good jacket, will hold up on rainy days.

The search for proofs of God's existence is its own genre, winding through history and sprouting capricious branches. Like any genre, from impressionist painting to romance novels, proof has never spoken for any whole society. It's rarely anyone's sole occupation, but still it has occupied some of history's most brilliant men.

I do mean men. As it happens, the genre comes to us through history as almost entirely an undertaking of men, making this story, by implication, a study of masculinity. It's a story of what a communion mostly of male minds has fashioned through this ongoing conversation over thousands of years, with their arguments speaking to each other more than to those around them, but more to those around them than they realize. It's also about what ideas they, thanks to whom they exclude, leave out.

These men have had big ambitions for their proofs. Plato thought that proofs of the gods might finally set his society right, that he could reform criminals just by reciting them. Ibn Tufayl, a

Muslim in medieval Spain, imagined a proof powerful enough to soothe away the will to live. The Jewish heretic Spinoza turned a venerable proof for God into one for an apparently godless universe. Descartes and Leibniz intended their proofs to heal the rift that the Reformation had driven through Europe. And the genre continues today, as much as ever, if

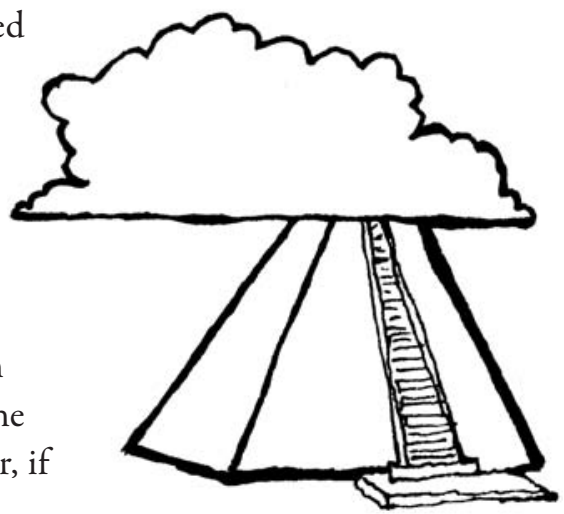


not more. In Turkey, I met a man trying to bring peace to the Middle East through proofs of divine beauty in nature. I've spent weeks driving around the suburbs of Southern California, from storefront to storefront, visiting organizations that promulgate one proof or another. I've attended classes by William Lane Craig, God's most fearsome advocate on today's debating circuit, and sat down with his archnemesis, Richard Dawkins. They're all out to rejigger the world and themselves and us in the process.

So how exactly is it that some people think that they can prove God exists, or doesn't, and why do others fall short? How did ancient arguments transform into an outgrowth of the culture wars? Why is it that for some of us everything depends on these proofs, while for others they're completely beside the point? These questions of we then throw themselves back on me again. I've had to think about abstractions and my own very real life in tandem.

The proofs show up in textbook after textbook, torn away from the flesh from which they came. ${ }^{2}$ They're taught, argued about, and forgotten, sometimes saving a person's particular faith, sometimes eroding it, and usually neither. There's no surer way of knowing than proof, by definition, and it's hard to imagine any more enticing knowledge than that of a God. Still, the world goes on in disagreement, in belief and unbelieving, with so many forms of each. Some few keep up the search for proof of a God, and for the hallelujahs that would surely come from finding one. While tracing their steps, though, I keep getting stuck trying to figure what God we're talking about, what existence might mean, and what, exactly, we expect from a proof. My own proof has never become much more than a possibility and an expectation, but that hasn't kept it from commandeering my life. 

